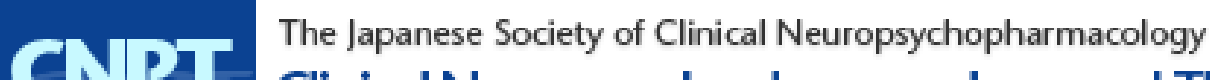 Clinical Neuropsychopharmacology and Therapeutics
}

\section{Lithium Intoxication Associated with Angiotensin II Type 1 Receptor Blockers in Women}

\author{
Takahiko Nagamine, M.D., Ph.D. \\ Division of Psychiatric Internal Medicine, Ishii Memorial Hospital, \\ 3-102-1Tada, Iwakuni city, Yamaguchi, 741-8585, Japan
}

Received November 29, 2013 / Accepted December 3, 2013 / Published December 26, 2013

Lithium is like a two-edged sword; it is on the one hand a unique drug with psychoactive potential as a mood stabilizer and on the other hand a burdensome drug which can cause multisystem toxicity to alter basic cellular function. Many drugs interact with lithium, increasing its blood level. For example, elevated lithium concentrations after the initiation of angiotensin-converting enzyme (ACE) inhibitors have been well documented in literatures [1][2][3]. However interaction between angiotensin II type 1 receptor (AT1R) blockers and lithium is rarely documented. We present a case of lithium intoxication after administration of telmisartan, an AT1R blocker, and examined reported cases of lithium intoxication by AT1R blockers.

A 48-year old woman with a 30-year history of schizoaffective disorder was hospitalized for relapse due to poor compliance. After being given medications including lithium $1,200 \mathrm{mg} /$ day, sodium valproate $400 \mathrm{mg} /$ day, olanzapine $20 \mathrm{mg} /$ day, levomepromazine $5 \mathrm{mg}$ /day, and clonazepam $2 \mathrm{mg} /$ day, the patient's condition had been stable for a period of time. However the patient developed sustained hypertension (150-170/90-110 $\mathrm{mmHg}$ ) about 2 months after the admission and was diagnosed with essential hypertension. Telmisartan $40 \mathrm{mg}$ /day was prescribed to control blood pressure. At this time, routine examination revealed normal renal, liver and thyroid functions. The serum lithium concentration before the addition of telmisartan was $0.96-1.01 \mathrm{mEq} / \mathrm{L}$ for lithium 1,200 $\mathrm{mg} /$ day. Her blood pressure was gradually decreased to $120-130 / 70-90 \mathrm{mmHg}$ by telmisartan. However the patient suddenly experienced slurred speech, unsteady gait, and confusion 24 days after the initiation of telmisartan. Laboratory results at this time were as follows: lithium concentration, $3.06 \mathrm{mEq} / \mathrm{L}$; valproate concentration, $38 \mu \mathrm{g} / \mathrm{mL}$; clonazepam concentration, $12.4 \mathrm{ng} / \mathrm{mL}$; blood urine nitrogen, 24.0 $\mathrm{mg} / \mathrm{dL}$; creatinine, $1.87 \mathrm{mg} / \mathrm{dL}$; sodium, $139 \mathrm{mEq} / \mathrm{L}$; potassium, $3.6 \mathrm{mEq} / \mathrm{L}$; and chloride, $101 \mathrm{mEq} / \mathrm{L}$. The patient was diagnosed as having lithium intoxication with acute renal failure. All drugs were discontinued and the patient was sent to the emergency department of a general hospital to receive intensive care.

The exact mechanism of lithium intoxication associated with AT1R blockers remains unclear, but it is supposed that natriuresis induced by AT1R blockers facilitate the retention of lithium from the kidney. Angiotensin II leads to stimulation of sodium reabsorption in the proximal tubules and secretion of aldosterone by the adrenal cortex. AT1R blockers might have resulted in decreasing sodium reabsorption in the proximal tubules and the decrease of aldosterone has a similar effect in distal tubules. Subsequently, the depletion of sodium might have in turn contributed to lithium reabsorption, eventually leading to lithium intoxication [1][2][3].

To our knowledge, there were seven case reports of lithium intoxication associated with AT1R blockers, including our case, and all of them were women shown in Table 1 [4][5][6][7][8][9]. Drug interaction between lithium and AT1R blockers might be more likely to occur in women. On the contrary, the sex differences are not recognized in ACE inhibitor-

Corresponding Author: Takahiko Nagamine, M.D., Ph.D., Division of Psychiatric Internal Medicine, Ishii Memorial Hospital, 3-102-1Tada, Iwakuni city, Yamaguchi, 741-8585, Japan.

e-mail: anagamine@yahoo.co.jp 
induced lithium intoxication. For example, Lehmann et al. examined 10 cases of lithium intoxication associated with ACE inhibitors, and 6 cases were men [1]. What is the reason why sex differences are recognized in the development of lithium intoxication induced by AT1R blockers?

One possible reason is that telmisartan has agonistic activities on peroxisome proliferator activated receptor- $\gamma$ (PPAR $\gamma)$ in which sex differences may exist [10]. Thiazolidinediones (TZDs) are agonists for PPAR $\gamma$ and the use of TZDs is associated with plasma volume expansion. TZDs rapidly stimulate sodiumcoupled bicarbonate absorption from the renal proximal tubules, resulted in reduced excretion of lithium and free water without changing creatinine clearance or urinary sodium excretion [11]. Consistent with the stimulation of proximal tubules transport through the activation of PPAR $\gamma$, a reduction in lithium clearance might have occurred in patients treated with telmisartan. Interestingly, TZD-induced volume expansion is high in incidence in women. Mechanism of sex differences in TZD-induced fluid retention is still unknown, but it is speculated that estrogen and progesterone might have enhanced the PPAR $\gamma$-dependent nongenomic stimulation of renal proximal transport by modulating $\mathrm{Na} / \mathrm{K}$ ATPase in renal tissues [12].

Another reason is that there are sex differences in angiotensin II type 2 receptor (AT2R) expression. Selective intrarenal AT1R blockade induced a highly significant natriruesis that was abolished by intrarenal coadministration of AT2R specific antagonist, indicating that the natriuretic effect of AT1R blockers is mediated by AT2R activation [13]. AT2R elicits natriuretic effects and these effects are greater in female due to enhanced AT2R levels modulated by estrogen [14]. Subsequently, marked natriuresis due to AT1R blockade might have occurred in females, leading to more lithium reabsorption in women than in men.

Further studies are needed to determine whether AT1R blockers have more potential risk of lithium intoxication in women than in men. Anyway lithium's narrow therapeutic index requires frequent serum concentration monitoring and a reduction in the dose of lithium when combining AT1R blockers.

Table 1. Reported Cases of Lithium Intoxication Associated with AT1R Blockers

\begin{tabular}{|c|c|c|c|c|c|c|}
\hline $\begin{array}{c}\text { Age } \\
(\text { y.o. })\end{array}$ & Sex & Disease & AT1R Blocker & $\begin{array}{c}\text { Lithium Dose } \\
(\mathrm{mg} / \text { day })\end{array}$ & $\begin{array}{c}\text { Lithium Level } \\
(\mathrm{mEg} / \mathrm{L})\end{array}$ & Reference \\
\hline 77 & female & bipolar & $\begin{array}{c}\text { losartan } \\
50 \mathrm{mg} / \text { day }\end{array}$ & 625 & 2 & 4 \\
\hline 51 & female & bipolar & $\begin{array}{c}\text { valsartan } \\
80 \mathrm{mg} / \text { day }\end{array}$ & 750 & 1.4 & 5 \\
\hline 58 & female & bipolar & $\begin{array}{c}\text { candesartan } \\
16 \mathrm{mg} / \text { day }\end{array}$ & 900 & 3.25 & 6 \\
\hline 74 & female & bipolar & $\begin{array}{c}\text { irbesartan } \\
300 \mathrm{mg} / \text { day }\end{array}$ & 750 & 2.3 & 7 \\
\hline 60 & female & bipolar & $\begin{array}{c}\text { valsartan } \\
80 \mathrm{mg} / \text { day }\end{array}$ & 600 & 1.72 & 8 \\
\hline 52 & female & schizoaffective & $\begin{array}{c}\text { termisartan } \\
40 \mathrm{mg} / \text { day }\end{array}$ & 900 & 2.6 & 9 \\
\hline 48 & female & schizoaffective & $\begin{array}{c}\text { termisartan } \\
40 \mathrm{mg} / \text { day }\end{array}$ & 1200 & 3.06 & this report \\
\hline
\end{tabular}

\section{REFERENCES}

[1] Lehmann K, Ritz E. Angiotensin-converting enzyme inhibitors may cause renal dysfunction in patients on long-term lithium treatment. Am J Kidney Dis. 1995 Jan;25(1):82-7.

[2] Chandragiri SS, Pasol E, Gallagher RM. Lithium ACE inhibitors, NSAIDs, and verapamil. A possible fatal combination. Psychosomatics. 1998 May-Jun;39(3):281-2.

[3] Handler J. Lithium and antihypertensive medication: a potentially dangerous interaction.
J Clin Hypertens (Greenwich). 2009 Dec;11(12):738-42.

[4] Blanche P, Raynaud E, Kerob D, Galezowski N. Lithium intoxication in an elderly patient after combined treatment with losartan. Eur J Clin Pharmacol. 1997;52(6):501.

[5] Leung M, Remick RA. Potential drug interaction between lithium and valsartan. J Clin Psychopharmacol. 2000 Jun;20(3):392-3.

[6] Zwanzger P, Marcuse A, Boerner RJ, Walther A, Rupprecht R. Lithium intoxication after administration of AT1 blockers.J Clin Psychia- 
try. 2001 Mar;62(3):208-9.

[7] Spinewine A, Schoevaerdts D, Mwenge GB, Swine C, Dive A. Drug-induced lithium intoxication: a case report. J Am Geriatr Soc. 2005 Feb;53(2):360-1.

[8] Su YP, Chang CJ, Hwang TJ. Lithium intoxication after valsartan treatment. Psychiatry Clin Neurosci. 2007 Apr;61(2):204.

[9] Ma CC, Shiah IS, Chang SW, Kao YC, Lee WK. Telmisartan-induced lithium intoxication in a patient with schizoaffective disorder. Psychiatry Clin Neurosci. 2012 Mar;66(2): 165-6.

[10] Kusunoki H, Taniyama Y, Azuma J, Iekushi K, Sanada F, Otsu R, Iwabayashi M, Okayama K, Rakugi H, Morishita R. Telmisartan exerts renoprotective actions via peroxisome proliferator-activated receptor- $\gamma /$ hepatocyte growth factor pathway independent of angiotensin II type 1 receptor blockade. Hypertension. 2012 Feb;59(2):308-16.

[11] Endo Y, Suzuki M, Yamada H, Horita S, Kunimi M, Yamazaki O, Shirai A, Nakamura M, Iso-O N, Li Y, Hara M, Tsukamoto $\mathrm{K}$, Moriyama N, Kudo A, Kawakami H, Yamauchi T, Kubota N, Kadowaki T, Kume H, Enomoto Y, Homma Y, Seki G, Fujita T. Thiazolidinediones enhance sodium-coupled bicarbonate absorption from renal proximal tubules via PPAR $\gamma$-dependent nongenomic signaling. Cell Metab. 2011 May 4;13(5):550-61

[12] Gracelli JB, Souza-Menezes J, Barbosa CM, Ornellas FS, Takiya CM, Alves LM, Wengert M, Feltran Gda S, Caruso-Neves C, Moyses MR, Prota LF, Morales MM. Role of estrogen and progesterone in the modulation of CNG-A1 and $\mathrm{Na} / \mathrm{K}+$-ATPase expression in the renal cortex. Cell Physiol Biochem. 2012;30(1):160-72.

[13] Carey RM. The intrarenal renin-angiotensin and dopaminergic systems: control of renal sodium excretion and blood pressure. Hypertension. 2013 Mar;61(3):673-80.

[14] Hilliard LM, Mirabito KM, Denton KM. Unmasking the potential of the angiotensin AT2 receptor as a therapeutic target in hypertension in men and women: what we know and what we still need to find out. Clin Exp Pharmacol Physiol. 2013 Aug;40(8):542-50. 